\title{
TINDAKAN ABORSI DALAM SUDUT PANDANG \\ HUKUM DAN KESEHATAN DI INDONESIA
}

Oleh :

Widowati

widowati.p4@gmail.com

\begin{abstract}
Abstraksi :
Aborsi merupakan suatu tindakan menggugurkan kandungan. Di negara Indonesia tindakan tersebut merupakan yang dilarang, dan masuk dalam Bab Kejahatan terhadap nyawa dalam Kitab Undang-Undang Hukum Pidana. Meskipun aborsi secara hukum terlarang, tetapi kenyataannya aborsi masih banyak dilakukan oleh perempuan dengan berbagai alasan disebabkan peraturan dan hukum yang ada kurang akomodatif terhadap alasan-alasan yang memaksa perempuan melakukan tindakan aborsi. Secara umum, pengguguran kandungan dapat dibagi menjadi 2 macam, yaitu: pengguguran tanpa sengaja dan pengguguran disengaja. Aborsi tanpa sengaja adalah pengguguran tidak sengaja yang terjadi tanpa tindakan apapun. Sedangkan aborsi disengaja adalah pengguguran yang terjadi sebagai akibat dari suatu tindakan. Aborsi dalam bentuk kedua ini dapat dibedakan dalam 2 macam, yaitu aborsi articialis therapicus dan aborsi procatus criminalis. Aborsi articialis therapicus adalah pengguguran yang dilakukan oleh dokter atas dasar indikasi medis yang dilakukan sebagai penyelamatan terhadap jiwa ibu yang terancam bila kelangsungan kehamilan dipertahankan. Sedangkan aborsi provocatus criminalis adalah pengguguran yang dilakukan tanpa dasar indikasi medis misalnya, aborsi yang dilakukan untuk meniadakan hasil hubungan seks diluar perkawinan atau untuk mengakhiri perkawinan yang tidak dikehendaki.
\end{abstract}

\section{Kata kunci: Aborsi, Hukum, Kesehatan.}

\section{A. Latar Belakang Permasalahan}

Kemajuan pembangunan disegala bidang selalu membawa dampak bagi masyarakat suatu bangsa. Begitu juga untuk bangsa Indonesia. Salah satu masalah penduduk yang dihadapi bangsa Indonesia dewasa ini adalah tata pergaulan generasi muda yang dimasa sekarang ini sangatlah bebas. Padahal mereka pada gilirannya akan menjadi generasi penerus cita-cita bangsa.

Sementara itu dari mereka menyandang keterlantaran. Kondisi seperti ini perlu ditangani secara sungguh-sungguh. Banyak anak yang terlantar baik jasmaniah dan 
rohaniahnya maupun segi sosialnya. Hal ini sangat berpengaruh terhadap perkembangan dan pembentukan jiwa dan kepribadiannya. Salah satu contoh dalam hal pergaulan anakanak muda sekarang cenderung semakin ada kebebasan dalam berinteraksi. Pergeseran perilaku itu sering memunculkan sebuah masalah baru di lingkungan masyarakatnya. Hal ini menunjukkan tingkat pergaulan bebas semakin tahun semakin meningkat, seiring dengan meningkatnya dunia tehnologi yang semakin canggih, yang lebih memudahkan masyarakat untuk mendapatkan segala sesuatu yang dikehendaki.

Dalam kenyataannya masih banyak anak-anak yang secara bebas menonton ved porno, kurang perhatian dari orang tua yang menyebabkan broken home, pengaruh lingkungan, pengaruh obat-obatan terlarang sehingga menyebabkan anak melakukan perbuatan yang melanggar norma susila dan norma agama.

Pengaruh ini berkaitan langsung dengan segi teknologi, lingkungan, sosial dan ekonomi. Untuk sektor lain diarahkan pula pencegahan timbulnya pergaulan bebas pemuda dan pemudi dengan fungsi dan bidangnya masing-masing (pendidikan, disiplin, sosial, kerohanian, kesehatan, kasing sayang dan bimbingan orang tua dan sebagainya). Kebijaksanaan dan pemupukan anti pergaulan bebas merupakan perwujudan rasa tanggung jawab sosial masyarakat, baik melalui prganisasi yang bersifat positif ataupun kegiatan lain yang bersifat memupuk kepribadian yang baik bagi pemuda dan pemudi.

Dalam hal pergaulan bebas para pemuda pemudi, bahkan anak dibawah umurpun bisa melakukan perbuatan yang sekarang bisa berakibat fatal. Misalnya, mereka sering menirukan adegan-adegan porno yang mereka tonton baik melalui televise maupun media social yang lainnya. Hal ini akan mengakibatkan kehamilan di luar pernikahan. Disini beban mental untuk wanita semakin berat. Dia akan menanggung malu jika si pria tidak mau bertanggung jawab. Akhirnya timbulah gagasan yang tidak baik untuk menghilangkan rasa malu itu dengan cara aborsi (pengguguran kandungan). Dari sisi lain bisa jadi inisiatif untuk menggugurkan kandungan itu datangnya dari keluarga pihak laki-laki karena dianggapnya sebagai sebuah aib keluarga. Lagi-lagi pihak perempuan menjadi pihak yang disudutkan dan dikalahkan.. Selain itu juga aborsi bisa mengakibatkan gangguan kesehatan pada wanita dan juga bisa berakibat fatal pada kematian. 


\section{B. Rumusan Masalah}

1. Bagaimanakah pertanggungjawaban pidana terhadap pihak (seseorang / wanita) yang melakukan tindak pidana aborsi dan bagi pihak yang menyuruh atau memaksa untuk melakukan tindakan aborsi yang melawan hukum?

2. Bagaimana pula pertanggungjawaban seorang Dokter yang melakukan tindakan aborsi yang melawan hokum.

\section{Tujuan Penelitian}

Tujuan dari penelitian ini adalah untuk mencoba memberikan jawaban atas apa yang diangkat sebagai permasalahan, yaitu untuk memperoleh pengetahuan yang berhubungan dengan masalah yang dibahas. Menentukan alternatif pemecahan yang dianggap paling mudah dan terjangkau, sehingga permasalahan yang timbul segera dapat diatasi. Memberikan saran-saran yang dapat mendukung langkah-langkah pemecehan masalah dan menganalisa secara yuridis tentang tindak pidana aborsi yang dilakukan secara sengaja dan melawan hukum, dan faktor apa yang menyebabkan seseorang melakukan aborsi yang melawan hukum.

\section{Metode Penelitian}

Didalam penulisan ini digunakan metode diskriptif analisis. Dengan penelitian diskriptif diharapkan dapat menjelaskan kenyataan yang terjadi dalam masyarakat, mengupas secara terperinci suatu masalah untuk mencapai hasil yang diharapkan, dengan mengumpulkan data tulisan yang bersifat ilmiah dan menghubungkannya dengan kenyataan yang ada.

Adapun sumber data yang digunakan dalam penelitian normative ini, yaitu lebih dominan menggunakan data sekunder, sedangkan data primer digunakan untuk melengkapi data-data yang lainnya. Data sekunder dapat berupa perundang-undangan, buku literature, tulisan para sarjana, maupun diambil dari internet. 


\section{E. Tinjauan umum tentang aborsi.}

Pengertian aborsi secara umum adalah pengguguran kandungan. Aborsi bisa dilakukan secara sengaja ataupun tidak sengaja. Aborsi yang secara tidak sengaja dilakukan dapat terjadi akibat kecelakaan dan dikatakan aborsi yang tidak melawan hukum, artinya tindakan tersebut tidak menyalahi aturan hukum.

Sedangkan tindakan aborsi yang melawan hukum adalah tindakan yang menyalahi aturan hukum, lebih jelasnya pengguguran kandungan yang dilakukan secara sengaja dan dapat berakibat hukum (bisa berakibat pidana penjara menurut KUHP).

Tindakan aborsi yang melawan hukum sering terjadi tetapi jarang muncul kepermukaan, ini terjadi karena masing-masing pihak antara pasien dengan dokternya sama-sama bisa merahasiakan semua peristiwa aborsi tersebut.

Sebenarnya tindakan aborsi itu dilarang oleh undang-undang. Tetapi berdasarkan Undang-undang No 36 Tahun 2009 tentang Kesehatan dalam Pasal 75 ayat 2 terdapat perkecualian. Aborsi boleh saja dilaksanakan asal memenuhi beberapa ketentuan-ketentuan yang sudah menjadi dasar pokok yang tidak boleh dilanggar, baik dalam KUHP maupun aturan khusus yang sudah ditetapkan oleh Pemerintah. Aborsi yang dibenarkan menurut ketentuan aturan hukum karena untuk penyelamatan kesehatan ataupun nyawa seseorang, misalnya saja ada seorang ibu hamil yang kehamilannya di luar kandungan maka untuk menyelamatkan jiwa ibu tersebut perlu diadakan tindakan operasi guna mengangkat janin yang berada di luar kandungan itu karena tanpa diadakan tindakan operasi tersebut tidak menutup kemungkinan jiwa ibu hamil tersebut terancam.

Dipertegas lagi dalam Pasal 76 bahwadalam aborsi yang berindikasi medis sebagaimana yang dimaksud dalam Pasal 75 ada beberapa hal yang menjadi suatu persyaratan diantaranya adalah

a. Dengan persetujuan ibu hamil yang bersangkutan atau suami atau keluarganya.

b. Berdasarkan indikasi medis yang mengharuskan diambilnya tindakan tersebut.

c. Oleh tenaga kesehatan sesuai dalam ketentuan aturan. 
Aborsi yang masuk klasifikasi kriminal (Abortus Provocatus Criminalistis) yaitu tindakan aborsi yang tidak dibenarkan karena dalam KUHP tindakan aborsi diatur dalam pasal 346, pasal 347, pasal 348, dan pasal 349 KUHP, misalnya ada seorang wanita muda hamil karena alasan belum punya suami dank arena malu kalau diketahui oleh temantemannya maka ia bermaksud menggugurkan kandungannya dengan minta bantuan seorang dokter untuk dapatnya kandungannya digugurkan dengan memberi imbalan atas jasa dokter tersebut, aborsi seperti inilah yang tidak dibenarkan dalam KUHP, karena masuk dalam klasifikasi kriminal (Abortus Provocatus Criminalistis).

Abortus Spontanius yaitu suatu kejadian yang mengakibatkan kegugurannya suatu kehamilan dari seorang ibu hamil dikarenakan akibat terpleset, jatuh, kecelakaan atau kejadian yang lain, misalnya ada seorang ibu hamil saat mandi terpleset dan jatuh, dari kejadian ini telah terjadi pendarahan yang cukup banyak dan mengakibatkan kegugurannya kehamilan yang dikandungnya.

\section{F. Dasar Hukum Tindakan Aborsi yang Melawan Hukum menurut KUHP}

Pembahasan kasus ini mempergunakan beberapa dasar hukum yang menjadi dasar untuk menjawab permasalahan-permasalahan yang telah dikemukakan di atas. Dasar hukum untuk tindakan aborsi yang melawan hukum menurut KUHP antara lain:

\section{Kitab Undang-Undang Hukum Pidana :}

Seorang wanita yang sengaja menggugurkan atau mematikan kandungannya atau menyuruh orang lain untuk itu, diancam dengan pidana penjara paling lama empat tahun.

\section{Pasal 347 Kitab Undang-Undang Hukum Pidana :}

(1) Barang siapa dengan sengaja menyebabkan gugur atau mati kandungannya seorang perempuan tidak dengan ijin perempuan itu, dihukum penjara selama-lamanya dua belas tahun.

(2) Jika karena perbuatan itu perempuan itu jadi mati, dia dihukum penjara selamalamanya lima belas tahun. 


\section{Pasal 348 Kitab Undang-Undang Hukum Pidana :}

(1) Barang siapa dengan sengaja menyebabkan gugur atau mati kandungannya seorang perempuan dengan ijin perempuan itu dihukum penjara selama-lamanya lima tahun enam bulan.

(2) Jika karena perbuatan itu perempuan itu jadi mati, dia dihukum penjara selamalamanya tujuh tahun.

\section{Pasal 349 Kitab Undang-Undang Hukum Pidana :}

Jika seorang dokter, bidan atau juru obat membantu melakukan kejahatan tersebut pada pasal 346, ataupun melakukan atau membantu melakukan salah satu kejahatan yang diterangkan dalam pasal 347 dan 348, maka pidana yang ditentukan dalam pasal itu dapat ditambah dengan sepertiga dan dapat dicabut hak untuk menjalankan pencarian dalam mana kejahatan dilakukan.

\section{Pasal 55 (1) Kitab Undang-Undang Hukum Pidana :}

Pasal 55 (1) dipidana sebagai pembuat (dader) sesuatu perbuatan pidana :

Ke-1 mereka yang melakukan, yang menyuruh lakukan dan yang turut serta melakukan perbuatan

Ke-2 mereka yang dengan memberi atau menjanjikan sesuatu dengan menyalahgunakan kekuasaan atau martabat dengan kekerasan atau penyesatan, atau dengan memberi kesempatan, sarana atau keterangan, sengaja menganjurkan orang lain supaya melakukan perbuatan.

\section{G. Dasar Hukum Aborsi menurut Undang-Undang No. 36 Tahun 2009 tentang Kesehatan.}

Landasan atau dasar hukum aborsi yang sesuai dengan ketentuan diatas adalah tertuang dalam Pasal 75, pada ayat (1) terdapat larangan untuk melakukan Tindakan aborsi bagi setiap orang. Pada ayat (2) terdapat pengecualian dalam hal indikasi kedaruratan medis, dan juga adanya situasi yang sifatnya darurat pribadi yaitu kehamilan akibat perkosaan yang dapat menyebabkan trauma psikologis bagi korban perkosaan. Hal ini dilakukan dibawah pengawasan dan wewenang ahli Kesehatan. 
Pasal 76 aturan ini terdapat sejumlah persyaratan khusus yang harus dipatuhi ketika akan melakukan aborsi. Sehingga tidak bisa sembarangan untuk dilakukan. Sedangkan dalam Pasal 77 adalah kewajiban Pemerintah untuk memberikan perlindungan dan mencegah perempuan melakukan aborsi yang tidak bermutu, tidak aman, dan tidak bertanggung jawab serta bertentangan dengan norma agama dan ketentuan peraturan perundang-undangan.

\section{H. Penerapan Hukum untuk pertanggungjawaban pidana.}

Untuk menjawab bagaimana pertanggungjawaban pidana terhadap perbuatan yang dilakukan oleh seorang wanita yang sengaja menggugurkan kandungan dan seseorang yang menyuruh/memaksa seseorang untuk melakukan aborsi serta perbuatan dokter yang melakukan aborsi yang melawan hukum, apakah dapat dibenarkan ditinjau dari hukum positif yang ada baik menurut KUHP maupun Undang-Undang Kesehatan No. 36 Tahun 2009 maka akan diuraikan secara sistematis agar dapatnya berbagai ketentuan aturan hukum dapat disangkakan atau dituduhkan atas perbuatan yang dilakukan oleh pelakunya.

Dalam ketentuan pasal 346, 347 dan 348 KUHP disinggung tentang hal aborsi atau kematian kandungan seorang wanita. Disitu tidak dipergunakan istilah anak, akan tetapi istilah kandungan dan menggugurkan kandungan dinyatakan sebagai kejahatan tersendiri yang tidak termasuk dalam pengertian pembunuhan. Sebelum lahir janin dalam kandungan yang dapat digugurkan, sedangkan setelah lahir, anaklah yang dapat dibunuh (Pasal 342 KUHP).

Pasal-pasal 346, 347 dan 348 KUHP menunjuk kepada seluruh waktu kehamilan, sehingga secara yuridis tidak ada perbedaan antara kehamilan yang baru dua minggu dan yang sudah empat bulan. Walaupun demikian, di dalam praktek seolah-olah ada perbedaan terhadap perlindungan hukum atas kehamilan yang baru berusia dua minggu dan yang sudah berusia empat bulan (apalagi jika dikaitkan dengan program pelaksanaan KB di Indonesia).

Walaupun secara yuridis janin dalam kandungan belum berstatus manusia, ia tetap mempunyai sifat yuridis tersendiri. Janin di dalam kandungan merupakan kesatuan dengan ibunya, tetapi ia tidak dapat disamakan dengan bagian-bagian badan yang lain dari ibunya, karena ia mempunyai kehidupan sendiri. Ia hanya sementara di dalam badan ibunya. Dapat saja 
terjadi ibu meninggal dan janin dalam kandungannya masih hidup, atau sebaliknya janin mati tetap ibunya hidup terus.

Nasib janin dalam kandungan tidak boleh ditentukan sewenang-wenang, misalnya wanita hamil tidak boleh memutuskan untuk mengganggu kehidupan janin atau menggugurkannya. Wanita itu boleh menentukan sendiri untuk menjadi hamil, tetapi sejak telurnya menjadi janin (embrio) wanita itu tidak lagi mempunyai hak sepenuhnya menentukan nasib tentang diri embrio itu, karena janin itu sudah mendapat perlindungan hukum tersendiri (Status nascendi). ${ }^{1}$

Permasalahan pertama yang perlu dibahas dalam hal ini adalah :

Apakah yang dimaksud dengan kalimat "menggugurkan anak yang berada dalam kandungan" atau yang dalam Bahasa belanda disebut "afdrijving"?

Istilah yang lazim dipergunakan dalam ilmu pengetahuan hukum adalah istilah romawi yaitu "Abortus" atau secara lengkapnya "Abortus Provocatus".

Adapun yang dimaksudkan dengan abortus atau afdrijving itu ialah perbuatan yang dilakukan dengan sengaja dengan maksud agar anak yang masih berada dalam kandungan ibu dilahirkan sebelum tiba waktunya menurut alam. Sedang yang dimaksud dengan "menggugurkan seorang anak dari kandungan si ibu" adalah apa yang dalam ilmu kedokteran adalah mengakibatkan anak dilahirkan sebelum tiba waktunya menurut alam.

Terhadap persoalan yang diajukan tersebut di atas terdapat beberapa sarjana berpendapat bahwa dalam perumusan ketentuan pasal 346 KUHP itu tidak ditegaskan bahwa si anak yang digugurkan itu masih harus hidup atau meninggal. Lebih lanjut para sarjana yang berpendapat demikian tadi mengatakan, bahwa oleh karena Undang-Undang sendiri tidak merumuskan secara tegas mengenai hal tersebut, maka tidak perduli apakah anak yang digugurkan itu masih hidup atau tidak, pokoknya semua itu termasuk di dalam pengertian abortus. $^{2}$

\footnotetext{
1 “Status Nascendi”. Hermin Hadiati, Sinar Wijaya, Surabaya, Tahun 1984.

2 "Kapita Selekta Kedokteran Edisi Ke Dua", Purnawan Junadi, Atik Soemasti, Husna Amelz, Aesculapius Fakultas Kedokteran UI, 1982.
} 
Janin yang berada dalam kandungan seorang ibu/seorang wanita itu sudah mempunyai hak untuk hidup dan telah dilindungi oleh hukum positif yang ada. Dengan demikian kita tidak boleh sewenang-wenang terhadapnya.

\section{Penerapan hukum untuk pertanggungjawaban pidana terhadap perbuatan yang dilakukan oleh seorang wanita yang sengaja melakukan aborsi dan seorang yang menyuruh/memaksa melakukan aborsi dengan janji atau imbalan}

1. Tindakan yang diperbuat si wanita yang sengaja menggugurkan kandungannya dapat dikenakan (dijerat) dengan pasal 346 KUHP.

Adapun beberapa unsur yang harus dipenuhi yaitu:

a. Seorang wanita;

b. Yang sengaja menggugurkan atau mematikan kandungannya atau menyuruh orang lain untuk itu;

c. Dipidana paling lama empat tahun.

Penjelasan terhadap unsur-unsur pasal 346 KUHP :

a. Seorang wanita.

Untuk pertama pasal 346 KUHP ini disebutkan seorang wanita "bukan seorang ibu" mengapa demikian sebab "wanita" dapat yang sudah menikah dan mempunyai anak (seorang ibu atau belum). Jika sudah menikah dan mempunyai anak ia disebut seorang ibu. Maka dipergunakan istilah itu agar dikenai pasal tersebut. Mengapa dipergunakan istilah "wanita" dan bukan "perempuan". Sebenarnya tidak ada perbedaan prinsipil, karena wujudnya sama saja. Tetapi kiranya ada latar belakang tertentu yang meninggalkan kesan kurang baik (dari sudut pendengaran). ${ }^{3}$

b. Sengaja menggugurkan atau mematikan kandungannya atau menyuruh orang lain untuk itu.

Apakah yang dilakukan oleh si wanita yang sengaja melakukan aborsi sesuai dengan salah satu diantara kedua jalan yang disebutkan dalam unsur ke dua.

\footnotetext{
${ }^{3}$ Sudarto, Wonosusanto, "Program Kekhususan Hukum Kepidanaan”, Fakultas Hukum Universitas Muhammadiyah Surakarta.
} 
Menggugurkan atau mematikan kandungan atau menyuruh orang lain untuk itu dalam pertimbangan kedua antara lain disebutkan bahwa :

“..... Si wanita hamil pada pokoknya mengakui bahwa ia telah sepakat dengan seseorang yang memaksa melakukan aborsi untuk menyuruh Dokter menggugurkan kandungannya (si wanita hamil tersebut) dan kemudian dokter melakukan dengan menyemprotkan obat Prostalglandrin ke dalam vagina wanita hamil tersebut, tidak berapa lama kemudian wanita itu ingin buang air kecil, ternyata yang keluar bukannya air kencing tetapi darah segar yang cukup banyak, darah itu berasal dari dalam kandungan wanita hamil tersebut, dan dokter diberi imbalan uang sebesar Rp. $500.000,00 "$.

c. Pidana penjara paling lama empat tahun.

Ancaman pidana penjara empat tahun itu adalah ancaman pidana maksimum artinya hakim bebas menjatuhkan pidana penjara berapa saja, asal tidak melewati batas empat tahun. Hal ini sesuai dengan redaksi pasal 346 pasal KUHP; seorang wanita yang sengaja menggugurkan kandungannya atau menyuruh orang lain untuk itu diancam pidana penjara paling lama empat tahun.

Perlu diperhatikan dalam pasal 346 KUHP, bahwa mematikan kandungan berarti mematikan anak yang masih hidup pada waktu dilakukan pengguguran adalah sukar atau mungkin juga tidak dapat dilakukan sama sekali. Dalam kalimat "dengan sengaja" menggugurkan kandungan tidak disinggung tentang keadaan anak, maksudnya tidak dipersoalkan apakah anak itu hidup atau mati pada saat lahir, begitu juga tidak disinggung usia anak dalam kandungan.

KUHP itu sendiri menentukan, hal mana berarti bahwa pengguguran dapat dilakukan sejak saat pembuahan sammpai saat anak hampir lahir. Mungkin sebelumnya sudah mati dalam kandungan pada waktu dilakukan pengguguran. Disini yang perlu diperhatikan ialah "perbuatan penggugurannya". 4

${ }^{4}$ Hermin Hadiati K, "Kejahatan Terhadap Nyawa, Azas-Azas” Sinar Wijaya, Surabaya, 1984. 
Seorang wanita hamil yang sengaja melakukan tindakan aborsi ini jelas ada motif, yaitu ia karena tergiur oleh janji yang diberikan oleh seseorang yang memaksa melakukan tindakan aborsi yang melawan hukum bahwa ia akan dinikahkan dengan putranya yang bernama Hendra Jaya. Bila kandungannya bersedia di gugurkan, maka ia bersedia untuk melaksanakan aborsi. Dari tindakan itu pula wanita itu telah menginsafi atau seharusnya mengerti bahwa tindakan yang dilakukan itu akan membawa akibat matinya bakal anak yang akan dilahirkan.

Memperhatian kasus pidana yang dilakukan oleh pihak yang sengaja menggugurkan kandungan tersebut, maka terpenuhi unsur-unsur dalam pasal 346 KUHP, dengan demikian dapat dinyatakan:

a. Seorang berjenis kelamin wanita yang sengaja menggugurkan kandungannya atas sepengetahuannya, misalnya dalam pernyataan contoh kasus di bawah adalah Ninik, umur 18 tahun asal Oro-oro Ombo Malang, kebangsaan Indonesia, bertempat tinggal di Tulungagung, agama Islam, pekerjaan sebagai karyawati bilyard, dinyatakan bersalah melakukan tindak pidana sebagaimana diatur dan diancam dalam pasal 346 Kitab Undang-Undang Hukum Pidana.

b. Dapat dijatuhi pidana penjara paling lama empat tahun.

2. Penerapan hukum untuk pertanggungjawaban pidana terhadap perbuatan yang dilakukan oleh seseorang/pihak yang menyuruh atau memaksa seseorang untuk menggugurkan kandungannya dengan adanya janji/iming-iming uang adalah sebagai berikut:

Tindakan pidana pihak tersebut dapat dijerat dengan pasal 55 (1) ke-1, ke-2 Kitab Undang-Undang Hukum Pidana, adapaun unsur-unsur yang harus dipenuhi masingmasing pasal itu sebagai berikut:

Untuk unsur pasal 55 (1) ke-1, ke-2 Kitab Undang-Undang adalah:

a. Adanya pembuat (dader) sesuatu perbuatan pidana.

Pembuat (dader) adalah seorang/mereka yang dengan sengaja memberikan, menyuruh dan turut serta melakukan suatu perbuatan. Dalam hal ini pembuat (dader) 
dengan kesengajaan memberikan gambaran atau rencana suatu perbuatan dan memaksa seseorang untuk melakukan perbuatan itu.

Dengan demikian seseorang (dalam contoh kasus adalah ibu Hanafi) yang memaksa melakukan tindakan aborsi yang melawan hukum dengan memberikan iming-iming atau janji-janji terhadap wanita hamil, di sini merupakan pembuat dari rencana aborsi terhadap kandungan pihak wanita hamil tersebut (dalam contoh kasus Siti Marfuah).

b. Adanya pemberian imbalan, menjanjikan sesuatu dengan penyalahgunaan wewenang atau martabat, dengan kekerasan, ancaman atau penyesatan, atau dengan memberikan kesempatan, sarana atau keterangan, sengaja menganjurkan orang lain supaya melakukan perbuatan.

Dalam hal ini ornag yang jelas-jelas menganjurkan seseorang untuk melakukan sesuatu perbuatan dengan memberikan janji-janji serta memberikan imbalan, seperti yang dilakukan terhadap wanita hamil (contoh kasus Siti Marfuah (Ninik)) juga terhadap dokter yang melakukan tindak aborsi yang melawan hukum (contoh kasus dokter pribadi Ny. Hanafi).

Bila diperhatikan perbuatan yang dilakukan oleh seseorang yang menyuruh melakukan aborsi ini, yang bersangkutan lebih tepatnya dapat di jarring dengan Pasal 55 (1) le-2 KUHP jo pasal 349 KUHP, dan bukan pasal 55 (1) ke-2 KUHP jo pasal 346 KUHP.

Hal ini dapat diambil satu kesimpulan bahwa:

Dalam contoh kasus : “.... bermufakatnya Ny. Hanafi dengan Siti Marfuah menyuruh orang lain, yaitu Dokter Rizal untuk menggugurkan kandungan Siti Marfuah, atas permintaan Ny. Hanafi dan Siti Marfuah tersebut, dokter melaksanakan dengan cara menyemprotkan obat Prostaglandrin ke vagina Siti Marfuah, dengan maksud dapat digugurkannya janin yang ada dalam kandungan Siti Marfuah, dan selanjutnya dokter mendapatkan upah atas jerih payahnya dari Ny. Hanafi berupa uang sebesar Rp. 500.000,00. 
Berdasarkan uraian diatas, maka terpenuhilah unsur-unsur pasal 55 (1) ke-2 KUHP jo pasal 349 KUHP.

Dengan demikian dapat ditarik kesimpulan bahwa keterlibatan Ibu Hanafi selaku pembuat (dader) suatu perbuatan pidana yang dilakukan dengan menyuruh, memberi saran, menjanjikan sesuatu kepada Siti Marfuah agar melakukan pengguguran kandungannya (tindak aborsi) maka kedudukannya disamakan dengan dokter sebagai pelaksanaan tindak aborsi itu, dengan demikian hukuman yang seharusnya diberikan sama dengan hukuman yang diberikan kepada dokter.

Jadi sangat tepatlah kalau Ibu Hanafi bukan didakwa dengan pasal 55 (1) ke-2 jo pasal 346 KUHP tetapi yang benar adalah pasal 55 (1) ke-2 jo pasal 349 KUHP.

Dari penjelasan di atas, dapatlah disimpulkan bahwa orang yang sengaja menyuruh dan memaksa seseorang untuk melakukan aborsi yang melawan hukum dengan memberikan janji-janji tersebut:

a. Dinyatakan bersalah telah melakukan tindak pidana yang diatur dalam pasal 55 (1) jo pasal 349 KUHP.

b. Dipidana penjara yang sama dengan dokter yaitu 5 tahun 6 bulan penjara potong masa tahanan.

\section{J. Penerapan hukum terhadap perbuatan dokter dalam menjalankan aborsi yang melawan hukum ditinjau dari hukum positif yang ada, baik menurut KUHP maupun dalam Undang-Undang Kesehatan tahun 1992 (UU RI No. 23 tahun 1992)}

Bila kita lihat lagi permasalahan yang ada dalam aborsi itu dimana dokter menyangkal bahwa tindakannya itu benar karena takut pasiennya (contoh kasus Siti Marfuah) melakukan bunuh diri lebih-lebih dengan alasan pasien terlihat stress berat, maka dokter tersebut terpaksa melakukan tindak aborsi semata-mata untuk menyelamatkan jiwa si ibu. 
Pada dasarnya alasan dokter itu tidak dapat dibenarkan karena tindakan terpaksa guna menyelamatkan si ibu itu bukan seperti yang dikatakan dokter itu sendiri, tetapi ada tersendiri ketentuan-ketentuan yang menjadikan dasar biasanya tindakan medis itu untuk dilakukan, baik itu yang diatur dalam KUHP maupun dalam Undang-Undang Kesehatan tahun 1992.

Tindakan pidana yang dilakukan oleh dokter dapat dijerat pasal 349 Kitab Undang-Undang Hukum Pidana dan pasal 15, 80 (1) Undang-Undang Kesehatan tahun 1992 (UU RI No. 23 tahun 1992).

a. Adapun unsur-unsur yang ada dalam masing-masing pasal diatas sebagai berikuUntuk penerapan pasal 349 Kitab Undang-Undang Hukum Pidana ini memiliki beberapa unsur sebagai berikut:

1. Tindakan pidana itu dilakukan oleh seorang dokter, bidan atau juru obat untuk membantu melakukan kejahatan yang tersebut dalam pasal 346, pasal 347 dan pasal 348 Kitab Undang-Undang Hukum Pidana.

Bila dilihat dari profesi-profesi yang ada di atas, sebenarnya memang sangat mungkin tindakan pengguguran kandungan/aborsi yang melawan hukum itu dilakukan, mengingat mereka-mereka itu benar-benar mengetahui cara dan obatobat yang harus dipergunakan, dengan demikian praktek-praktek aborsi secara tidak benar terjadi dimana-dimana, terutama dikota-kota besar.

2. Adanya penambahan pidana sepertiga dari pidana yang ditentukan dan dapat dicabut hak untuk untuk menjalankan pencarian dalam mana kejahatan itu dilakukan.

Dalam hal ini diadakan penambahan pidana terhadap tindakan yang dilakukan dokter, bidan atau juru obat, karena dianggap mereka yang seharusnya lebih mengetahui tentang tindakan aborsi yang dibenarkan dan yang tidak dibenarkan, justru melakukan tindakan aborsi yang dilarang atau yang tidak sesuai dengan ketentuan-ketentuan yang sudah ada, selain itu perlu juga diadakan pencabutan hak untuk menjalankan pencarian/praktek, karena dianggap mereka telah menyalah gunakan profesinya ke jalan yang tidak seharusnya dijalankan. 
b. Dalam penerapan pasal 15 Undang-Undang Kesehatan tahun 1992 (UU RI No. 23 tahun 1992) terdapat beberapa ketentuan-ketentuan tentang tindakan aborsi yang benar dan yang seharusnya menjadikan dasar untuk menjalankan aborsi.

1. Adanya keadaan darurat sebagai upaya penyelamatan jiwa ibu hamil dan atau janinnya, dapat dilakukan tindakan medis tertentu.

Aborsi yang berindikasi medis ini merupakan tindakan aborsi yang dapat dibenarkan dan memenuhi ketentuan yang ada dalam Undang-Undang Kesehatan tahun 1992 (UU RI No. 23 tahun 1992).

2. Tindakan medis tertentu yang dimaksud di atas hanya dapat dilakukan:

- Berdasarkan indikasi medis yang mengharuskan diambilnya tindakan tersebut oleh tenaga kesehatan yang mempunyai keahlian dan kewenangan untuk itu dan dilakukan sesuai dengan tanggung jawab profesi serta berdasarkan pertimbangan tim ahli (disini tim dokter yang benar-benar ahli dalam melakukan tindakan medis).

- Adanya persetujuan ibu hamil tersebut, suami atau keluarga.

- Pada sarana kesehatan tertentu.

c. Dalam penerapan pasal 80 (1) Undang-Undang Kesehatan tahun 1992 (UU RI No. 23 tahun 1992), terdapat beberapa unsur yang terpenuhi yaitu:

1. Adanya kesengajaan tindakan medis tertentu terhadap ibu hamil yang tidak memenuhi ketentuan sebagaimana diatur dalam pasal 15 ayat (1) dan ayat (2) Undang-Undang Kesehatan No. 23 tahun 1992 (UU RI No. 23 tahun 1992).

Kesengajaan tindakan medis tertentu yang tidak memenuhi ketentuan ini, dimaksudkan tindakan yang sengaja dilakukan oleh pihak-pihak tertentu/seseorang dengan menyalahi ketentuan yang ada untuk memenuhi kepentingan pribadi.

2. Adanya pidana penjara paling lama lima belas tahun (15 tahun) dan pidana denda paling banyak Rp. 500.000.000,00 (lima ratus juta rupiah).

Dalam penerapan hukum untuk bisanya menjerat tindakan yang dilakukan oleh dokter yang melakukan aborsi dan melawan hukum sehubungan dengan tindakan aborsi yang dilakukan terhadap contoh kasus Siti Marfuah (Ninik) ini, 
ada persamaan dan perbedaan yang mendasar antara pasal-pasal yang ada dalam Kitab Undang-Undang Hukum Pidana dengan Undang-Undang Kesehatan tahun 1992 (UU RI No. 23 tahun 1992) yaitu:

- Persamaannya:

1. Adanya larangan terhadap tindakan aborsi yang dilakukan dengan kesengajaan tanpa memenuhi ketentuan-ketentuan yang ada.

2. Adanya ancaman pidana bagi yang melakukan tindakan pengguguran kandungan (aborsi) yang tidak sesuai atau menyalahi ketentuan yang sudah ada.

- Perbedaannya:

1. Dalam Kitab Undang-Undang Hukum Pidana, ancaman yang diberikan berupa pidana penjara dan pencabutan hak untuk menjalankan pencarian/praktek dalam mana kejahatan dilakukan.

2. Dalam Undang-Undang Kesehatan tahun 1992 (UU RI No. 23 tahun 1992) ancaman yang diberikan hanya berupa pidana penjara dan pidana denda, sementara pencabutan hak untuk menjalankan pencarian/praktek dalam mana kejahatan dilakukan, tidak ada.

Dengan adanya 2 aturan yang dapat dikenakan terhadap tindak pidana dokter ini, maka terjadi adanya concursus idealis. Istilah concursus idealis seperti concursus realis tidak terdapat dalam Undang-Undang. Pengertiannya terdapat dalam pasal 63 KUHP yang berbunyi:

(1) Jika suatu perbuatan masuk dalam lebih dari satu aturan pidana maka yang dikenakan hanya satu diantara aturan-aturan itu, jika berbeda-beda yang dikenakan yang memuat ancaman pidana pokok yang paling berat.

(2) Jika sesuatu perbuatan (feit) yang masuk dalam suatu aturan pidana, yang umum diatur pula dalam aturan pidana yang khusus itulah yang dikenakan.

Sepintas lalu aturan itu mudah, ialah apabila seseorang melakukan perbuatan yang masuk dalam lebih dari satu aturan pidana, maka yang dikenakan hanya satu aturan. 
Letak kerusakan pertama yang dimaksud dengan perkataan "perbuatan" atau dalam teks asli pasal 65 KUHP itu istilah "Feit".

Perbuatan disini dipikirkan terlepas dari akibat yang ditimbulkan, terlepas dari unsur-unsur tambahan. Misalnya dalam pembunuhan, perbuatan materiilnya dapat berupa menembak, memukul dan sebagainya. Dalam delik merusak dapat berupa membanting, memukul dan sebagainya. Jadi menurut pendapat ini yang termasuk concursus idealis ialah : apabila seseorang dengan melakukan perbuatan jasmaniah melanggar beberapa peraturan pidana. Dalam contoh-contoh di bawah ini apabila dipakai ukuran feit, maka terdapat concursus idealis.

1. Perkosaan di jalan umum (melanggar pasal 281 dan 285 KUHP).

2. Membakar rumah dapat berupa pembakaran (pasal 187 KUHP) dan perusakan barang (pasal 406 KUHP).

3. Menembak orang sampai mati dan sekaligus memecahkan kaca di belakang dimana orang tersebut berada (pasal 338 dan 406 KUHP).

4. Menembak dengan satu tembakan yang mengakibatkan seorang mati dan seorang luka berat (pasal 338, pasal 354, dan pasal 406 KUHP).

Pasal 63 KUHP menyatakan bahwa yang diterapkan satu aturan pidana. Disini dipakai sistem absorpsi, jika ada perbedaan dalam peraturan pidana maka yang dikenakan adalah yang terberat.

Dengan melihat dua aturan yang mengenai tindak pidana Dokter Rizal tadi yang dimana terjadi concursus idealis, maka sesuai pasal 63 (2) KUHP, Undang-Undang Kesehatan tahun 1992 sebagai aturan pidana khusus mengatur tentang tindakan seorang dokter sangatlah tepat dikenai tindak pidana yang dilakukan dokter dan bukan yang ada dalam KUHP.

Jadi dakwaan Jaksa Penuntut Umum dan Keputusan Hakim pada dasarnya kurang tepat, mengingat Undang-Undang Kesehatan tahun 1992 sebagai aturan yang lebih khusus maka Dokter Rizal dapat dijerat dengan pasal 80 (1) Undang-Undang Kesehatan tahun 1992 (UU RI No. 23 tahun 1992) yang terdapat ancaman pidana penjara selama-lamanya 
15 (lima belas) tahun dan pidana denda paling banyak Rp. 500.000.000,00 (lima ratus juta rupiah) dan bukan yang ada dalam pasal 349 KUHP.

\section{K. Penerapan hukum dan pertanggungjawaban Pengadilan Negeri dalam pelaksanaan aborsi yang berindikasi medis.}

Atas dasar yang diberlakukan KUHP dan Undang-Undang Kesehatan tahun 1992 (UU RI No. 23 tahun 1992), yaitu dalam aborsi yang berindikasi medis yang dilakukan oleh Tim ahli tidak perlu mengadakan persetujuan lebih dahulu kepada pihak Pengadilan Negeri, karena tim ahli medis sudah punya surat khusus/dasar hukum dan wewenang yang kuat.

Dalam pelaksanaan aborsi Tim ahli sudah memperhitungkan hal-hal mana yang perlu dilakukan dalam aborsi. Oleh karenanya Tim medis sudah memiliki kekuatan yang syah dan kuat dan terlindungi oleh Undang-Undang yang akurat didalam tugasnya dalam hal yang berhubungan dengan abborsi demi keselamatan jiwa pasiennya.

\section{Penutup}

a. Kesimpulan

Dari perumusan masalah yang telah diuraikan diatas, kesimpulan yang dapat diambil adalah sebagai berikut:

1. Aborsi atau sering disebut dengan tindakan pengguguran kandungan, banyak sekali dilakukan dalam praktek-praktek dokter, ahli obat maupun bidan. Jarang sekali peristiwa aborsi muncul keluar/kepermukaan sebagai suatu kasus yang dapat diselesaikan di muka pengadilan, karena masing-masing pihak dapat merahasiakannya dengan rapi. Tindakan aborsi yang sengaja dilakukan oleh seorang wanita secara umum dinyatakan bersalah melakukan tindak pidana sebagaimana diatur dan diancam dalam Pasal 346 KUHP dan dijatuhi pidana penjara paling lama empat tahun.

Bagi seorang (sebagai dader) yang sengaja menyuruh/memaksa melakukan dan turut serta melakukan menggugurkan kandungan orang lain dengan memberi imbalan, seseorang sebagai dader sesuatu perbuatan pidana dapat dijerat Pasal 55 (1) ke-2 Kitab 
Undang-Undang Hukum Pidana jo Pasal 349 dipidana penjara paling lama lima tahun enam bulan potong masa tahanan.

2. Sedangkan tindak pidana yang dilakukan oleh seorang dokter yaitu telah melakukan aborsi dan membantu seorang dader tersebut dengan menyalahgunakan wewenang dan ketentuan yang ada maka dapat dijerat dengan pasal 349 Kitab Undang-Undang Hukum Pidana, Undang-Undang Kesehatan tahun 1992 (UU RI No. 23 tahun 1992) dalam pasal 15 dan pasal 80 (1). Dokter tersebut dapat dipidana penjara paling lama lima belas tahun dan denda sebesar Rp. 500.000.000,00 (lima ratus juta rupiah) dan adanya pencabutan hak untuk praktek/melakukan pencaharian. Dalam tindakan aborsi yang berindikasi medis tidak perlu diadakan persetujuan lebih dahulu kepada pihak Pengadilan Negeri, karena dalam hal ini tim ahli medis yang berwenang sudah mempunyai surat tugas/mandate yang dilindungi oleh Undang-Undang mengenai aborsi yaitu berpedoman pada KUHP dan Undang-Undang Kesehatan pasal 15 tahun 1992 (UU RI No. 23 tahun 1992).

\section{b. Saran-Saran}

1. Untuk menekan sedikit mungkin frekuensi abortus seyogyanya anggota masyarakat betul-betul menghayati agama yang dianutnya sehingga di dalam berperilaku tetap terkontrol dan tidak ceroboh. Selain itu masyarakat harus memperhatikan dan melaksanakan norma-norma yang ada yaitu selain norma agama juga ada norma susila. Didikan dan pantauan serta pengawasan para orang tua terhadap anak-anaknya sangatlah dominan.

2. Undang-Undang diciptakan untuk mengatur perilaku manusia, oleh karena itu hendaknya ditaati. Di dalam kasus ini seorang dokter seyogyanya dapat bertindak bijaksana dan tidak terhanyut oleh bujukan pasien yang kadang-kadang mencelakakan. Meskipun dokter tersebut diiming-imingi dengan imbalan yang besar.

Adanya penyuluhan hukum khususnya berkaitan dengan pasal-pasal abortus, sehingga masyarakat mengetahui bahwa abortus itu merupakan kejahatan yang cukup tinggi ancaman pidananya dan segi norma agama juga dilarang. Dengan 
mengetahui hal tersebut, diharapkan laju abortus dapat ditekan karena masyarakat telah sadar akan akibat abortus dilihat dari segi positif dan segi negatif. Bila seseorang terpaksa harus melakukan aborsi secara medis, maka tidak perlu persetujuan dari Pengadilan Negeri, karena hal tersebut sudah dilindungi oleh UU Kesehatan.

\section{DAFTAR PUSTAKA}

Hermin Hadiati Koeswadji, Kejahatan Terhadap Nyawa, Azas-Azas, Kasus dan Permasalahan, 1994.

H. Mochamad Martoprawiro, Adji Dharma, Petrus Andrianto, Tentang Gawat Darurat Ginekologi dan Obstetri, Buku Kedokteran (FKUI), Jakarta, 1983.

Purnawan Junadi, Atik S. Soemasto, Husna Amelz, Kapita Selekta Kedokteran Edisi ke dua, Media Aesculapius Fakultas Kedokteran UI, 1982.

R. Soesilo, Kitab Undang-Undang Hukum Pidana, Politeia - Bogor, 1983.

Sudarto, Wonosutanto, Catatan Kuliah Hukum Pidana II, Program Kekhususan Hukum Kepidanaan, Fakultas Hukum Universitas Muhammadiyah, Surakarta 1994.

Soekanto Soerjono, Pokok-Pokok Sosiologi Hukum, Rajawali, Jakarta, 1984.

Soerojo Wignyodipoero, Pengantar dan Azas-Azas Hukum Adat, Cetakan VII, Masagung, Jakarta, 1988.

Sudarto, Wonosutanto, Catatan Kuliah Hukum Pidana II, Program Kekhususan Hukum Kepidanaan, Fakultas Hukum Universitas Muhammadiyah Surakarta, 1994.

Undang-Undang RI No. 23 tahun 1992, Tentang Undang-Undang Kesehatan, Sinar Grafika pasal 15 (2), Jakarta. 